Web Site: https://jutq.utq.edu.iq/index.php/main

Email: journal@jutq.utq.edu.iq

\title{
Frequency Mode Locking in Erbium Doped Fiber Laser
}

\section{https://doi.org/10.32792/utq/utj/vol12/1/4}

\section{Dhyaa . F. Hassan , Hassan. A. Yasser \\ Thi-Qar University, College of Science, \\ Physics Department}

\begin{abstract}
:
In this research, may insert of all the effects, such as dispersion, nonlinear, gain factor associated with the pumping pulse, attenuation and others in the conclusion the general equation for the propagation of the optical fiber through the laser resonator. In addition, the introduction of the effect of mode locking process using frequency modulation in order to get a stream ultrashort pulses. Selecting an suitable frequency modulated pulses achieved the stream could reach the stage of stability according to a certain number of trips round-trip (RT), since the highest frequency accompanied by a number less than the RT. On the other hand, the increase in $\mathrm{R}$ adversely affect the output pulses stream. The interval time between resulted pulses is inversely proportional to frequency modulated. stream pulses can be stable in the energy and pulse width with RT appropriate. increase factor $\beta_{2}$ contribute to stability of pulses energy while $\beta_{3}$ did not show any effects. The effect of the pumping energy represent of the $g_{0}$ worker showed that resulting energy increases with increases this factor. Pulse width $T_{0}$ initial and factor $T_{2}$ and modulated depth representing of their effects change method the oscillation of the factors resulting pulses.
\end{abstract}




\section{University of Thi-Qar Journal Vol.12 No.1 Mar 2017 \\ Web Site: https://jutq.utq.edu.iq/index.php/main \\ Email: journal@jutq.utq.edu.iq}

Keywords: fiber laser, mode mocking, erbium.

\section{Introduction}

Interest in ultrashort optical pulse sources is rapidly growing due to the wide range of emerging areas where subpicosecond pulses are providing new advances. Mode locked fiber lasers are reliable, compact and cost- effective sources of stable subpicosecond pulses. Fiber lasers offer a set of properties suitable for the generation of ultrashort pulses through mode locking techniques, either active or passive [1]. A simple and powerful approach for understanding the basic dynamical behavior of a laser is based on a rate equation model, in which simple balance equations for the total number of atoms undergoing a transition and the total number of photons created or annihilated are written. For a morerefined treatment of laser dynamics based on either a semiclassical or a full-quantum electro dynamic approach, which may account for certain phenomena such as dynamical laser instabilities, laser coherence and photon statistics [2].

Many optically pumped lasers have a gain medium consisting of rare earth or transition metal ions doped into an insulating dielectric solid. These are termed solid state lasers, and include laser erbium [3]. The gain of erbium doped fiber lasers (EDFLs) depends on many parameters such as erbium-ion concentration, amplifiers length, core radius, and pump power [4]. Many of the properties of a laser can be determined from a rate-equation model for the populations of the laser levels and the number of photons in the laser cavity [5]. All laser cavities share two characteristics that complement each other: 1) they are basically linear 


\section{University of Thi-Qar Journal Vol.12 No.1 Mar 2017 \\ Web Site: https://jutq.utq.edu.iq/index.php/main \\ Email: journal@jutq.utq.edu.iq}

devices with one relatively long optical axis and 2) the sides parallel to this axis can be open, not enclosed by reflecting material as in a microwave cavity [6]. The most common types of laser cavity is known as the Fabry-Perot cavity, which is made by placing the gain medium in between two high-reflecting mirrors. In the case of fiber lasers, mirrors are often butt-coupled to the fiber ends to avoid diffraction losses [7].

In the Fabry-Perot laser cavity The light makes two passes through the gain medium per round-trip (RT). Laser system consists of a set of mirrors and a gain medium. The gain medium is an optical amplifier which coherently amplifies light passing through it. The mirrors may be curved or planar and together make up the laser cavity or resonator. The cavity is aligned so that light reflects back and forth again and again, passing along the same path every time [8]. The mirrors of the laser keep photons from escaping completely, By making the mirrors partially transmitting, some of the photons are allowed to escape. They constitute the output laser beam. The intensity of the output laser beam is determined by the rate of production of excited atoms, the reflectivities of the mirrors, and certain properties of the active atoms [6]. Alignment of such a cavity is not easy since cavity losses increase rapidly with a tilt of the fiber end or the mirror, where tolerable tilts are less than $1^{\circ}$. This problem can be solved by several methods, including use fiber gratings as mirrors [4].

In this papers gives derivation of basic wave equation, followed by the theory of pulse propagation in dispersive optical medium. Moreover, the discussion of amplification in fibers, the physics of 


\section{University of Thi-Qar Journal Vol.12 No.1 Mar 2017 \\ Web Site: https://jutq.utq.edu.iq/index.php/main \\ Email: journal@jutq.utq.edu.iq}

frequency mode locking, and the required numerical analyses will presented.

\section{Modeling of Fiber laser with Mode locking}

The rate equations provide a simple and intuitive, yet accurate, picture of the behavior of lasers. In the most simplified form, the increase in photon number within the laser cavity is balanced by the decrease in the population difference between the upper and lower laser levels [9]. The EDFL can be modeled using the propagation and rate equations for a homogeneous two-level laser medium. Optical pumping creates the necessary population inversion between the two energy states, which in turn provides the optical gain (peak gain ) $g_{p}=\sigma\left(N_{2}-N_{1}\right)$, where $\sigma$ is the transition cross section and $N_{1}, N_{2}$ are the atomic densities for the lower and upper energy levels of the two-level system [4].

In general, the local gain coefficient $g_{p}$ is a function of optical frequency due to the limited optical bandwidth. It is also a function of optical power because of the saturation effect, which can be expressed as [5]

$$
g_{p}=\frac{g_{0}}{1+\left(\omega-\omega_{a}\right)^{2} T_{2}^{2}+P_{\text {ave }} / P_{\text {sat }}}
$$

where $g_{0}, T_{2}, P_{\text {sat }}$ represent the maximum small signal gain, the dipole relaxation time, and the saturation power, respectively and $w$ is the optical frequency, $w_{a}$ is the atomic resonance frequency. The equation

$$
P_{\text {ave }}=\frac{1}{T_{m}} \int_{T_{m} / 2}^{T_{m} / 2}|A|^{2} d t
$$




\section{University of Thi-Qar Journal Vol.12 No.1 Mar 2017 \\ Web Site: https://jutq.utq.edu.iq/index.php/main \\ Email: journal@jutq.utq.edu.iq}

represents the average power passing through the gain medium (for mode locked laser), where $T_{m}$ is the spacing between adjacent pulses and is inversely related to the repetition rate of the system [10]. To simplify the discussion, let $\left(\omega=\omega_{a}\right)$ we obtain [7]

$$
g_{p}=\frac{g_{0}}{1+P_{\text {ave }} / P_{\text {sat }}}
$$

The nonlinear Schrodinger equation (NLSE) is the fundamental mathematical device for analyzing nonlinear pulse propagation in fibers[11]. If the slowly varying amplitude $A$ of the optical pulse is normalized in such a way that $|A|^{2}$ represents optical power, the NLSE for a standard optical fiber has the form [12]

$$
\frac{\partial A}{\partial z}-\sum_{m=0}^{\infty} \frac{j^{m+1}}{m !} \beta_{m} \frac{\partial^{m} A}{\partial t^{m}}=-\frac{\alpha}{2} A+j \gamma|A|^{2} A
$$

where $A=A(z, t)$, the nonlinear coefficient is $\gamma=w_{o} \bar{n}_{2} / c A_{\text {eff }}, \omega_{0}$ is the reference frequency relative to which the slowly varying envelop approximation was made, $A_{\text {eff }}$ is the effective mode area and $\beta_{m}=\left(\partial^{m} \beta / \partial w^{m}\right)_{w_{o}}$ are the dispersion parameters [13]. Here, we will generalized this equation so that it can be applied for EDFL. When dopants such as erbium are introduced into a fiber, all these effects of the host medium are inherited by the doped fibers and can affect the performance of EDFL. Therefore, modifications must be introduced to the standard NLSE to account for the presence of dopants [5]. The 


\section{University of Thi-Qar Journal Vol.12 No.1 Mar 2017 \\ Web Site: https://jutq.utq.edu.iq/index.php/main \\ Email: journal@jutq.utq.edu.iq}

propagation of an optical pulse in a fiber is characterized by a mode propagation constant $\beta(\omega)$. The mode propagation constant $\beta(\omega)$ can be expanded in a Taylor series about $\omega_{0}$ to get [7]

$$
\beta_{f}(\omega)=\beta_{0}+\left(\omega-\omega_{0}\right) \beta_{1}+\frac{1}{2}\left(\omega-\omega_{0}\right)^{2} \beta_{2}+\frac{1}{6}\left(\omega-\omega_{0}\right)^{2} \beta_{3}+\ldots=\sum_{m=0}^{\infty} \frac{\left(\omega-\omega_{0}\right)^{\mathrm{m}} \beta_{m}}{m !}
$$

where $\beta_{0}$ is the wave number. For pulses having widths in the picosecond range, the susceptibility of the dopants can be written as[4,5]

$$
\chi_{\mathrm{a}}(\omega)=\frac{g_{p} c n(\omega)}{\omega} \frac{1}{j+\left(\omega-\omega_{a}\right) T_{2}}
$$

$n(\omega)$ is the refractive index of the fiber core in the absence of doping, the dipole relaxation time $T_{2}$. The relative permittivity or dielectric constant of a doped fiber is obtained by adding the contribution of the dopants to that of the undoped fiber. That is $[12,6]$

$$
\varepsilon=n^{2}+2 n \Delta n
$$

where $\Delta n$ represents the change of refractive index that defined as [4]

$$
\Delta n=\bar{n}_{2}|E|^{2}+j \frac{\alpha}{2 k}+\frac{\chi_{\mathrm{a}}(\omega)}{2 n}
$$

where $\alpha$ accounts for the fiber loss, $k=w / c$.

We have added the nonlinear contribution through the $\bar{n}_{2}$ term and the effect of dopant through $\chi_{a}(\omega)$. The absorptive and dispersive properties of the doped fiber result from the frequency dependence of 


\section{University of Thi-Qar Journal Vol.12 No.1 Mar 2017 \\ Web Site: https://jutq.utq.edu.iq/index.php/main \\ Email: journal@jutq.utq.edu.iq}

$\varepsilon(\omega)$ and $|E|^{2}=|A|^{2} / A_{\text {eff }}$ is the optical intensity. Substituting Eq.(8) into (7), may yields

$\sqrt{\varepsilon}=n \sqrt{1+\frac{2 \bar{n}_{2}|\mathrm{E}|^{2}}{n}+\frac{j \alpha}{n k}+\frac{\chi_{\mathrm{a}}(\omega)}{n^{2}}}$

Note that $\alpha, \bar{n}_{2}|E|^{2}$, and $\left|\chi_{a}(\omega)\right|$ are much smaller than $n(\omega)$. Hence, the square root on the right hand side may be extracted using Taylor series to yield

$$
\sqrt{\varepsilon} \approx n+\bar{n}_{2}|E|^{2}+\frac{j \alpha}{2 k}+\frac{\chi_{\mathrm{a}}(\omega)}{2 n}
$$

The propagation constant of the signal within the doped-fiber medium can be written as $\beta(\omega)=w \sqrt{\varepsilon(\omega)} / c$. Using the definitions of $\bar{n}_{2}$ and $|E|^{2}$, the second term will be $\gamma|A|^{2}$. The propagation constant in the undoped fiber is $\beta_{f}(\omega)=n w / c$. So the propagation constant will be

$$
\beta(\omega)=\beta_{f}(w)+\gamma|A|^{2}+j \frac{\alpha}{2}+\frac{\chi_{\mathrm{a}}}{2 n} \frac{\omega}{c}
$$

Using Eq.(5), Eq.(11) will be

$$
\beta(\omega)=\sum_{m=0}^{\infty} \frac{\left(\omega-\omega_{0}\right)^{\mathrm{m}} \beta_{m}}{m !}+\gamma|A|^{2}+j \frac{\alpha}{2}+\frac{\chi_{\mathrm{a}}}{2 n} \frac{\omega}{c}
$$

owing to the finite gain bandwidth associated with $\chi_{a}(\omega)$, all spectral components of the pulse do not experience the same gain, a phenomenon 


\section{University of Thi-Qar Journal Vol.12 No.1 Mar 2017 \\ Web Site: https://jutq.utq.edu.iq/index.php/main \\ Email: journal@jutq.utq.edu.iq}

referred to as gain dispersion [5]. Using Eq.(6), the last term in Eq.(12) will be

$$
\frac{\chi_{\mathrm{a}}(\omega) \omega}{2 n c}=\frac{g_{p}}{2} \frac{1}{\left(\omega-\omega_{a}\right) T_{2}+j}
$$

Expanding $\chi_{a}(\omega)$ in a Taylor series around $\omega_{0}$, the result becomes

$$
\frac{\chi_{\mathrm{a}}(\omega) \omega}{2 n c}=\frac{g_{p}}{2} \sum_{m=0}^{\infty}(-1)^{m}\left(\omega-\omega_{0}\right)^{m} \frac{T_{2}^{m}}{(\delta+j)^{m+1}}
$$

where $\delta=\left(\omega_{0}-\omega_{a}\right) T_{2}$ represents a detuning of the carrier frequency $\omega_{0}$ of the pulse from the atomic transition frequency $\omega_{a}$.Substituting Eq.(14) into (12), will give

$$
\beta(\omega)=\sum_{m=0}^{\infty} \frac{\left(\omega-\omega_{0}\right)^{\mathrm{m}} \beta_{m}}{m !}+\gamma|A|^{2}+j \frac{\alpha}{2}+\frac{g_{p}}{2} \sum_{m=0}^{\infty}(-1)^{m}\left(\omega-\omega_{0}\right)^{m} \frac{T_{2}^{m}}{(\delta+j)^{m+1}}
$$

For simplicity, let us also assume that the carrier frequency $\omega_{0}$ of the incident pulse is matched exactly to the gain peak occurring at atomic transition frequency $\omega_{a}$. So that $\delta \approx 0$ and Eq.(15) will be

$$
\beta(\omega)=\sum_{m=1}^{\infty} \frac{\left(\omega-\omega_{0}\right)^{\mathrm{m}}}{m !} \beta_{m}^{e f f}+\gamma|A|^{2}+j\left(\frac{\alpha}{2}-\frac{g_{p}}{2}\right)
$$

where

$$
\beta_{m}^{e f f}=\beta_{m}+\frac{g_{p}}{2} m ! j^{m-1} T_{2}^{m} \quad, m=1,2,3, \ldots .
$$

For example, the first three terms have the forms 


\section{University of Thi-Qar Journal Vol.12 No.1 Mar 2017}

Web Site: https://jutq.utq.edu.iq/index.php/main

Email: journal@jutq.utq.edu.iq

$$
\beta_{1}^{\mathrm{eff}}=\beta_{1}+\frac{g_{p} T_{2}}{2}, \beta_{2}^{\mathrm{eff}}=\beta_{2}+j g_{p} T_{2}^{2}, \beta_{3}^{\mathrm{eff}}=\beta_{3}-3 T_{2}^{3} g_{p} .
$$

with the introduction of the preceding effective parameters, we can write the propagation equation for an EDFL by replacing the corresponding parameters in the standard NLSE, i.e. Eq.(4), with the effective ones. The resulting equation will have the form

$$
\frac{\partial A}{\partial \mathrm{z}}+\beta_{1}^{\text {eff }} \frac{\partial A}{\partial t}-\sum_{m=2}^{\infty} \frac{j^{m+1} \beta_{m}^{e f f}}{m !} \frac{\partial^{m} A}{\partial t^{m}}=\left(\frac{g_{p}}{2}-\frac{\alpha}{2}\right) A+j \gamma|A|^{2} A
$$

Eq.(17) shows how the dispersion parameters of the host fiber change because of the dopant contribution. However, the dopant induced change in the group velocity is negligible in practice. This can be done through the following standard Galilean transformation $T=t-\beta_{1}^{\text {eff }} z$. Using this assumption, one may obtain

$$
\frac{\partial A}{\partial z}-j \sum_{m=2}^{\infty} \frac{j^{m} \beta_{m}^{e f f}}{m !} \frac{\partial^{m} A}{\partial T^{m}}=\left(\frac{g_{p}}{2}-\frac{\alpha}{2}\right) A+j \gamma|A|^{2} A
$$

where the two-photon contribution was added to keep the following analysis general $[4,5]$. In cases in which the mathematical structure of the preceding equation is paramount, it is better to recast it in normalized units.

The NLSE permits specific solution know as soliton, we introduce soliton transformations [12]

$$
\xi=\frac{z}{L_{\mathrm{D}}} \quad, \quad \tau=\frac{T}{T_{0}} \quad, \quad A(\xi, \tau)=\sqrt{P_{o}} U(\xi, \tau)
$$

where $L_{D}=T_{0}^{2} /\left|\beta_{2}\right|$ is the dispersion length and $T_{0}$ is the width of the input pulse. Using these transformations. Eq.(18) will be 


\section{University of Thi-Qar Journal Vol.12 No.1 Mar 2017 \\ Web Site: https://jutq.utq.edu.iq/index.php/main \\ Email: journal@jutq.utq.edu.iq}

$\frac{\partial U}{\partial \xi}-\sum_{m=2}^{\infty} \frac{j^{m+1} \beta_{m}^{e f f} L_{D}}{m ! T_{o}^{m}} \frac{\partial^{m} U}{\partial \tau^{m}}=\left(\frac{g_{p}}{2}-\frac{\alpha}{2}\right) L_{D} U+j N^{2}|U|^{2} U$

where $N^{2}=L_{D} \gamma P_{o}=L_{D} / L_{N L}$ is the soliton order and $L_{N L}=1 / \gamma P_{o}$ is the nonlinear length and $P_{0}$ is the peak power [14].

The active mode-locking fiber laser is attractive because it can offer a transform limited picosecond or subpicosecond pulse trains with very high repetition rate [15]. Active mode-locking works with a periodic phase modulation, even though this leads to chirped pulses .This technique is called FM mode-locking [16]. Optical ultra short pulse sources are the most attractive block in the photonic signal processing systems. FM mode locking can be selected because the generated pulse is shorter than that in the AM mode locking scheme [7]. In order to explain FM mode-locking, we will start with its effect on a field such that [10]

$$
M(U, \xi, \tau)=j \Delta_{F M}\left[\cos \left[\omega_{\mathrm{m}}\left(\tau-T_{s}(\xi)\right)\right]\right] \mathrm{U}(\xi, \tau)
$$

where $\Delta_{F M}$ modulation depth and $T_{s}(\xi)$ accounts for any detuning between the modulator and a harmonic of the cavity's repetition rate and $\omega_{m}=2 \pi F_{m}$ is angular modulation frequency [10,7]. Active mode locking requires modulation of either the amplitude or the phase of the intra cavity optical field at a frequency $F_{m}$ equal to (or a multiple of) the mode spacing $\Delta v$ [4]. From the relation $F_{m}=1 / T_{m}$ where is $T_{m}$ the round trip time, it is clear that to produce pulses much shorter than the round trip time the laser needs to oscillate at quite a few longitudinal modes 


\section{University of Thi-Qar Journal Vol.12 No.1 Mar 2017 \\ Web Site: https://jutq.utq.edu.iq/index.php/main \\ Email: journal@jutq.utq.edu.iq}

simultaneously [14]. The pulse width, $\tau_{\text {pulse }}$ is approximated by $T_{m} / M$; where, $M$ is the total number of phase locked modes. In a real modelocked laser, the actual pulse width depends on other factors, such as the pulse shape and the overall dispersion of the cavity [17]. Using Eq.(21) into (20), yields

$$
\frac{\partial U}{\partial \xi}-\sum_{m=2}^{\infty} \frac{j^{m+1} \beta_{m}^{e f f} L_{D}}{m ! T_{o}^{m}} \frac{\partial^{m} U}{\partial \tau^{m}}=\left(\frac{g_{p}}{2}-\frac{\alpha}{2}\right) L_{D} U+j N^{2}|U|^{2} U+j \Delta_{F M} \cos \omega_{\mathrm{m}} \tau \mathrm{U}
$$

\section{Results and Discussion}

The propagation of optical pulses in optical fiber is described using Eq.(4). The addition of dopant to fiber core will be modified this equation to the formula in Eq.(22), which includes the effects of dispersion and nonlinearity and the output gain coefficient due to the presence of dopant. Accordingly, using a piece of optical fiber and forming the resonator lead to solve this equation and the description laser output. The optical pumping process is performed by a strong other pulse that is called the pump. It's effects are presented by the impact factor $g_{p}$. After that, the introducing of the mode locking concept using frequency modulation technique to get a train of short pulses that repeat according to the period of time that is inversely proportional to the frequency $F_{m}$.

Solving Eq.(22) with presence of mode locking term requires using of the split-step Fourier method (SSFM) that depends on creating a grids of frequency and of time to deal with the pulses spectrally and temporally. Accuracy of these grids control the results clearly. This equation is solved by dividing the space of length also into small sections 


\section{University of Thi-Qar Journal Vol.12 No.1 Mar 2017 \\ Web Site: https://jutq.utq.edu.iq/index.php/main \\ Email: journal@jutq.utq.edu.iq}

$\Delta z$. The amount of $\Delta z$ should be chosen to maximize the results and minimize the truncation and turning errors.

To solve the equation on the resonator, it means resolved back and forth using the same division $\Delta z$ so that we can reach the required RT. This means that the equation will be solved thousands of times using the step $\Delta z$ on the resonator length $L$. Accordingly, the calculations require too much time every time up to more than 6 hours. This effect prevents us from using larger numbers of RT. To emphasize here that this may cause an increase in the truncation and turning errors.

Table (1) illustrates the values of coefficients used in the operation, which will consider as constant through all shapes resulting figures unless otherwise indicated .

Table (1) : Simulation parameters [17,16].

\begin{tabular}{|c|cc|c|c|}
\hline $\begin{array}{c}\text { Symbol } \\
\text { Paramete } \\
\mathbf{r}\end{array}$ & Value & $\begin{array}{c}\text { Symbol } \\
\text { Paramete } \\
\mathbf{r}\end{array}$ & Value \\
\hline$\gamma$ & $0.0012 \quad 1 / w . m$ & $\beta_{2}$ & $-1.4 \times 10^{-26} \mathrm{~s}^{2} / m$ \\
\hline$g_{0}$ & 0.8 & $1 / m$ & $\beta_{3}$ & $30 \times 10^{-41} s^{3} / m$ \\
\hline$E_{s}$ & 1 & $n J$ & $\alpha$ & $0.21 / m$ \\
\hline$T_{2}$ & \multicolumn{2}{|c|}{$50 n s$} & $\lambda_{c}$ & $1550 \quad n m$ \\
\hline$T_{0}$ & $100 \quad p s$ & $L$ & $4 \quad m$ \\
\hline$\Delta_{F M}$ & \multicolumn{2}{|c|}{0.4} & $R_{H R}$ & 0.99 \\
\hline$F_{m}$ & 20 & $M H z$ & $R_{O C}$ & 0.5 \\
\hline$T_{s}(\xi)$ & \multicolumn{2}{|c|}{0} & & \\
\hline
\end{tabular}




\section{University of Thi-Qar Journal Vol.12 No.1 Mar 2017 \\ Web Site: https://jutq.utq.edu.iq/index.php/main \\ Email: journal@jutq.utq.edu.iq}

Fig.(1) represents a pulse shape using different numbers of RT. It is evident from the figure that the input pulse is sech that will be faced to the deformation once its movement inside the resonator due to the generated stimulated radiation and presence the mode locking. With increasing RT the pulse begins deform, then make lobes and breaking to form a stream of ultrashort pulses. The energies of these pulses begin to oscillation with the increase in RT until it reaches the stabilization case. On the other hand, the distance between these short pulses also be oscillatory until to locke on the distance $T_{m}=1 / F_{m}$. However continue to move through the resonator after a short time, we will get a stream of regular pulses with the same energy and the time interval between them.

Fig.(2) represents stream of generated pulses for several cases of $F_{m} \quad R$ and a number of RT. It is clear that increasing RT leads to breaking the pulse to a train of pulses, the power of these pulses and the interval between them tend to stability with increase RT. With increased $R$ we note confusion incidence in the behavior of the resulted stream, and this is attributable to increasing the percentage of the reflected pulses energy inside the resonator. The fact that $R=50 \%$ makes high regularity of pulses by interval $F_{m}$. With increased $R$, it regularity become disturbed and the pulses are generated outside this interval of time and therefore, the power output will be less. From the other hand the generated pulses will be shifted increasaly with a decrease of $F_{m}$ and therefore, it means the difficulty in obtaining steady stream at small $F_{m}$ only after a large number of RT. The opposite happens at large $F_{m}$. The 


\section{University of Thi-Qar Journal Vol.12 No.1 Mar 2017 \\ Web Site: https://jutq.utq.edu.iq/index.php/main \\ Email: journal@jutq.utq.edu.iq}

small values $F_{m}$ has caused irregular stream of pulses that represents existence of pulses outside the intervals of the relationship $T_{m}=1 / F_{m}$. This irregular can be removed with increased RT and reduce $R$ to the limits of 50\%. Therefore the irregular output at small RT that is wellknown in the laser subject is linked to both the RT and $R$ and the frequency of mode locking technique. These three factors are essential control in the work of the laser to generate the required pulses.

Fig.(3) represents a stream of generated pulses with RT and different $F_{m}$. It is evident from the figure that the breaking rate with increases of $F_{m}$ and tendency to stabilization of stream pulses with increased RT. For certain value of the RT, we note that the stream is not symmetrical but rather varies by value of $F_{m}$. The difference is the lack of stability of the stream and separated time the intervals. Where we see that the stream at $F_{m}=25 \mathrm{MHz}$ stabilizes at $\mathrm{RT}=500$, whereas the frequency $F_{m}=20 \mathrm{MHz}$ causes the partial stability of for the stream at $\mathrm{RT}=1000$ and less than that for the least frequencies. In the stream summary the Fig.(2) and (3) the possibility to controlling pulses generated by identifying each of the $F_{m}$ and RT and the reflectivity with the steadying of all the other operators factors. Each pulse, generated in a resonator will cause a stream of the pulses within the limits of the original pulse ( $p s$ ). After a short period of time, a steady and stable stream of the ultrashort $(f s)$ pulses will generate.

Fig.(4) represents a form of ultrashort pulses, which are generated at the center of the initial input pulse at the times $T_{m}= \pm n / F_{m}$ where 


\section{University of Thi-Qar Journal Vol.12 No.1 Mar 2017 \\ Web Site: https://jutq.utq.edu.iq/index.php/main \\ Email: journal@jutq.utq.edu.iq}

$n=0, \pm 1, \pm 2, \pm 3, \pm 4$. The upper left corner represents the case $n=-4$ and lower right represents the case $n=4$ respectively. All the blue lines represent the shape of the pulses at different $\mathrm{RT}$ until it reaches the final step using $\mathrm{RT}=250$. It is clear that the generated pulses change in shape and power with increase of RT and whenever the greater RT, the value tends to stability. Note that, the pulse center will be at $(200, \ldots, 150-, 200-) p s$ and this refers to position of the pulse a related of to the center of initial proposed pulse. The pulses and by its proximity to the initial pulse center position will begin to emergence faster than the distant pulses, but with increase RT all that tends to stability, in particular using an appropriate values for $R$ and RT. 
Web Site: https://jutq.utq.edu.iq/index.php/main

Email: journal@jutq.utq.edu.iq
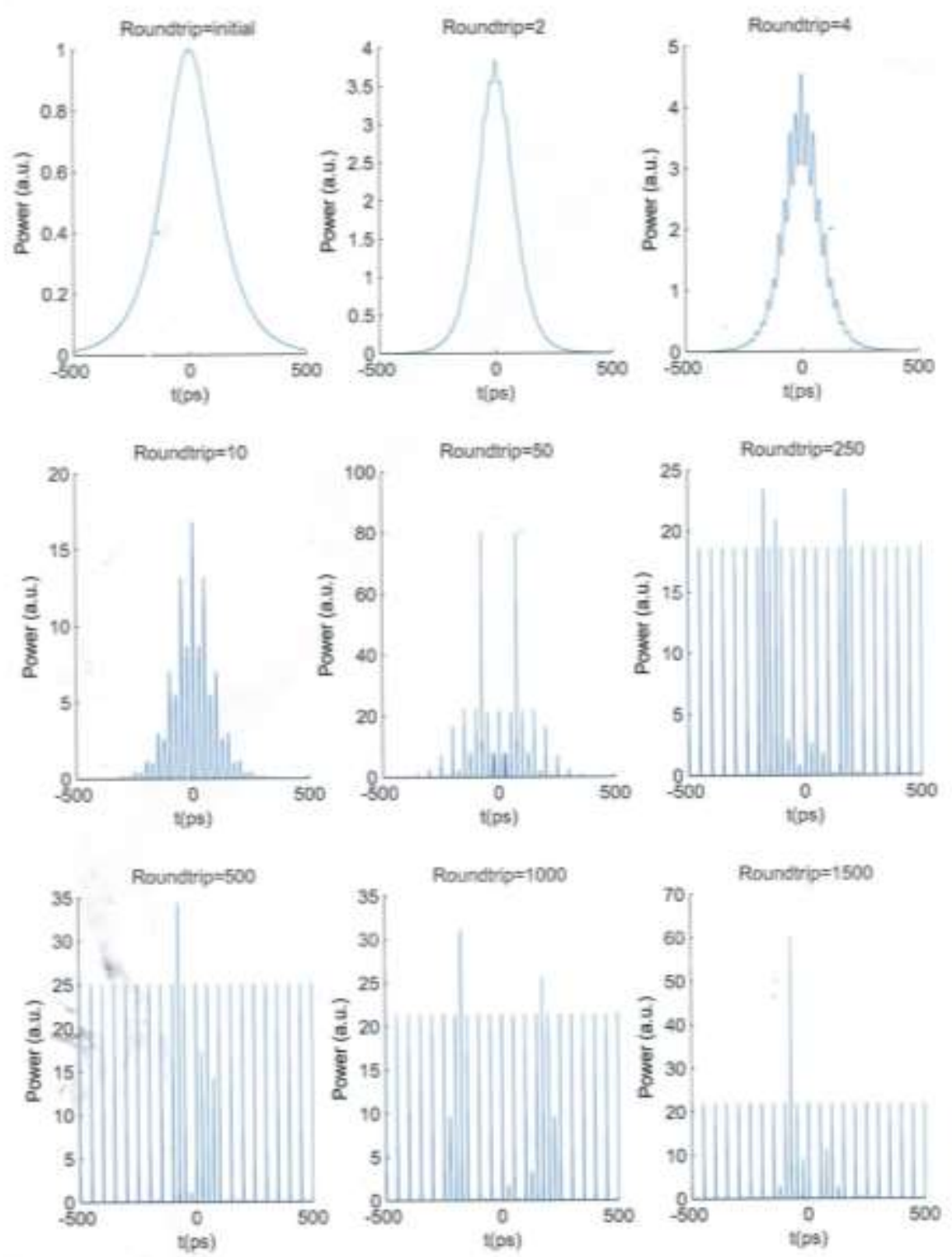

Fig.(1): The evolution of pulse with roundtrip, where pulse is segmention into many ultrashort roundtrip pulses 
University of Thi-Qar Journal Vol.12 No.1 Mar 2017

Web Site: https://jutq.utq.edu.iq/index.php/main

Email: journal@jutq.utq.edu.iq

with a time interval $T_{m}=1 / F_{m}$. Here $F_{m}=20 \mathrm{MHz}$.
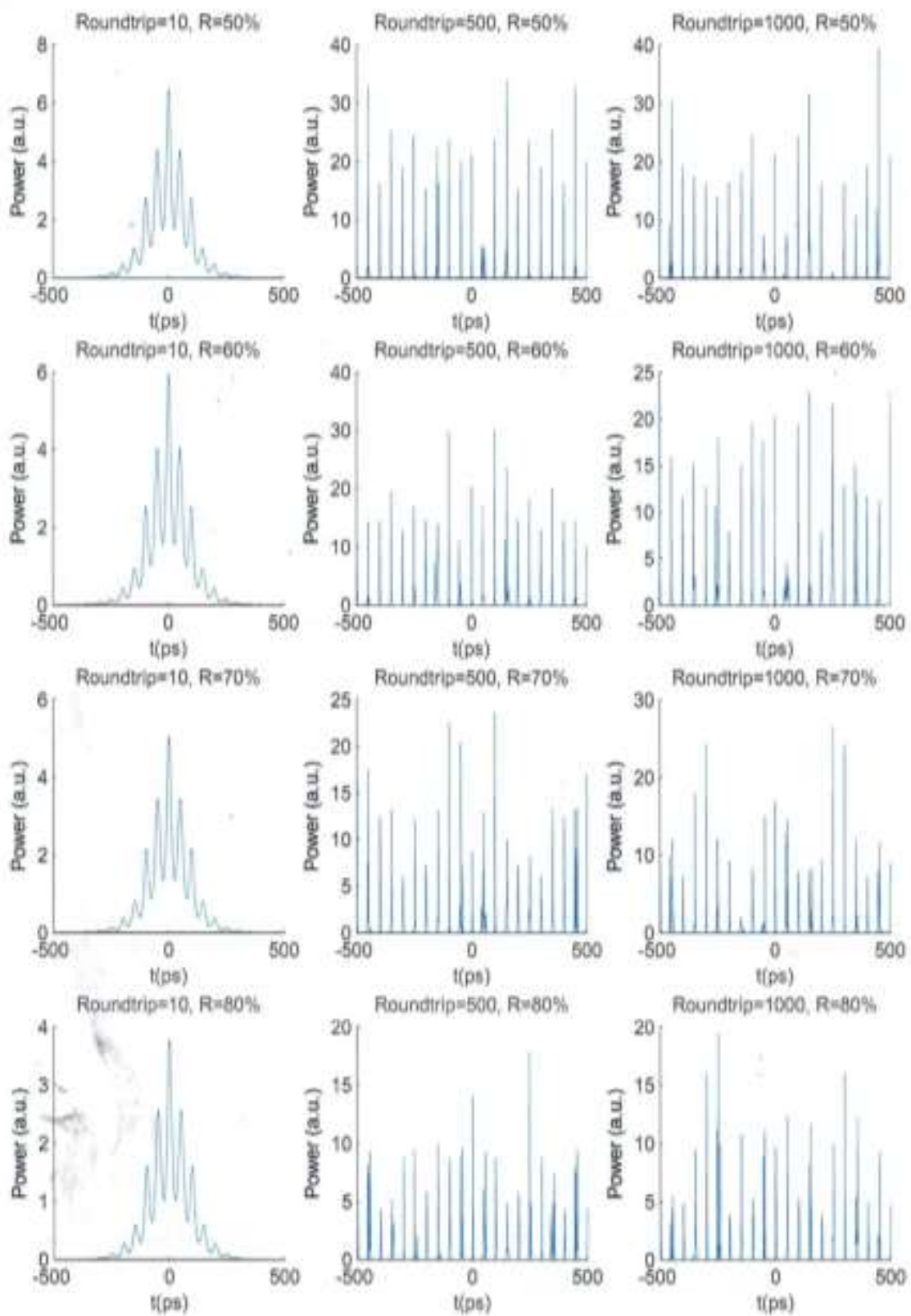

Fig.(2): The segmention process into ultrasho roundtrip 
University of Thi-Qar Journal Vol.12 No.1 Mar 2017

Web Site: https://jutq.utq.edu.iq/index.php/main

Email: journal@jutq.utq.edu.iq

pulses for different values of roundtrip and $R$ where

a) $F_{m}=10 \mathrm{MHz}$, b) $F_{m}=20 \mathrm{MHz}$ and c) $F_{m}=30 \mathrm{MHz}$. 


\section{University of Thi-Qar Journal Vol.12 No.1 Mar 2017 \\ Web Site: https://jutq.utq.edu.iq/index.php/main \\ Email: journal@jutq.utq.edu.iq}
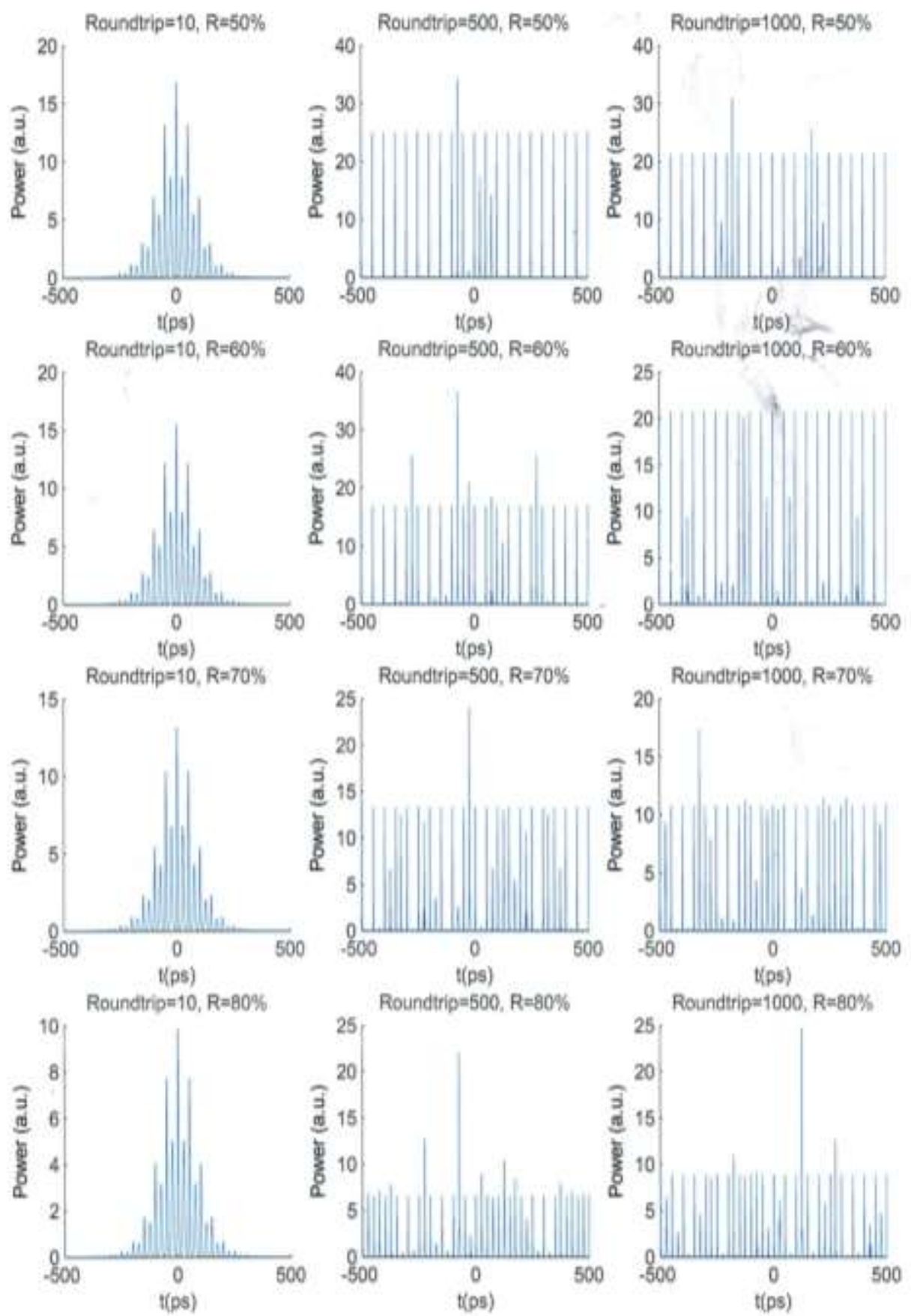
University of Thi-Qar Journal Vol.12 No.1 Mar 2017

Web Site: https://jutq.utq.edu.iq/index.php/main

Email: journal@jutq.utq.edu.iq

To be continued 


\section{University of Thi-Qar Journal Vol.12 No.1 Mar 2017 \\ Web Site: https://jutq.utq.edu.iq/index.php/main \\ Email: journal@jutq.utq.edu.iq}
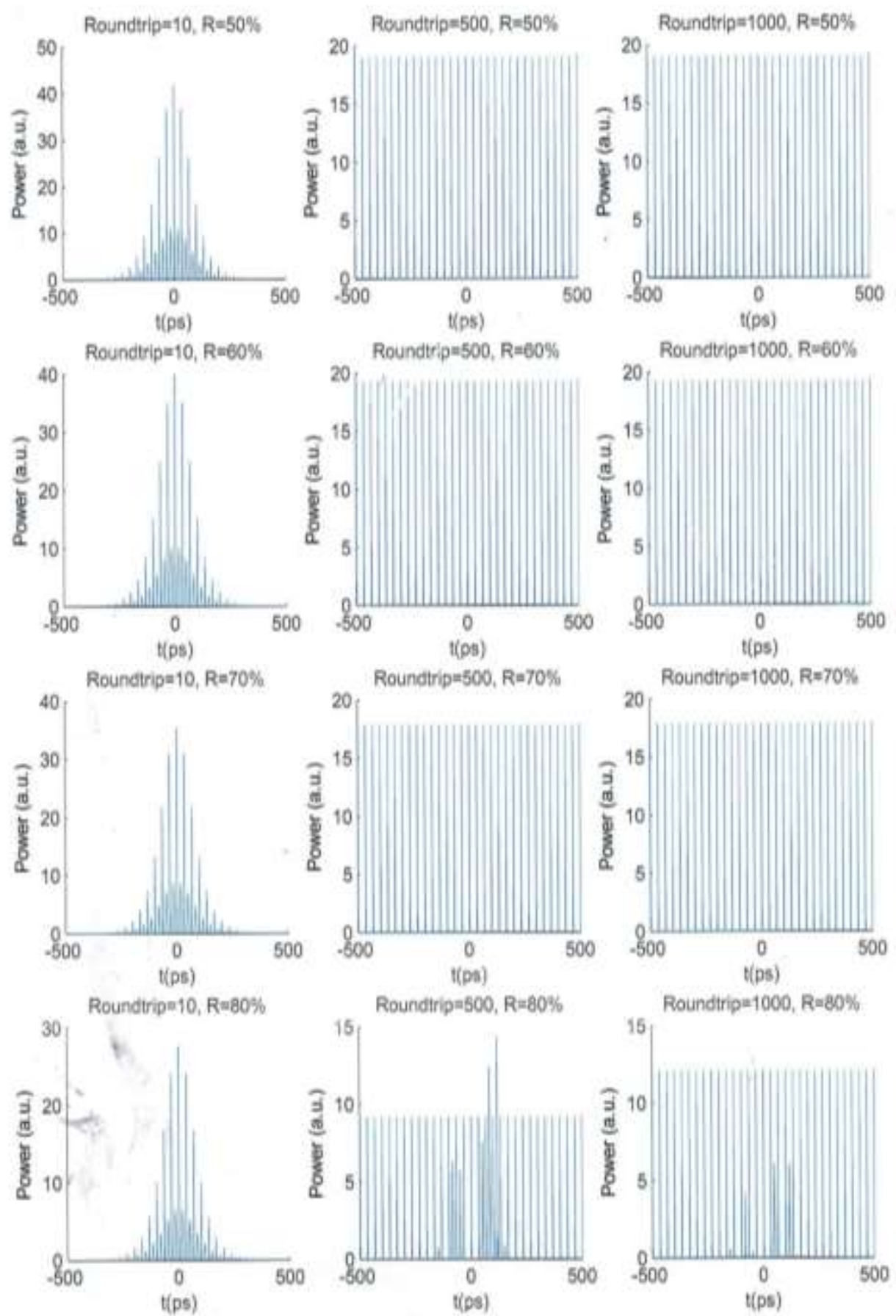
University of Thi-Qar Journal Vol.12 No.1 Mar 2017

Web Site: https://jutq.utq.edu.iq/index.php/main

Email: journal@jutq.utq.edu.iq

To be continued 
Web Site: https://jutq.utq.edu.iq/index.php/main

Email: journal@jutq.utq.edu.iq

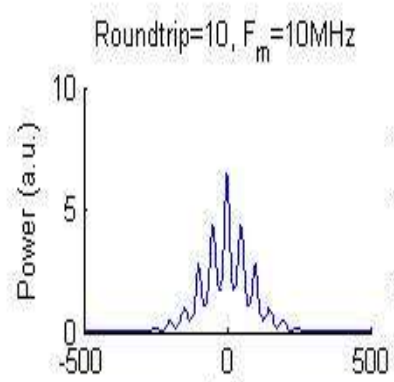

t(ps)

Roundtrip $=10, F_{m}=15 \mathrm{MHz}$

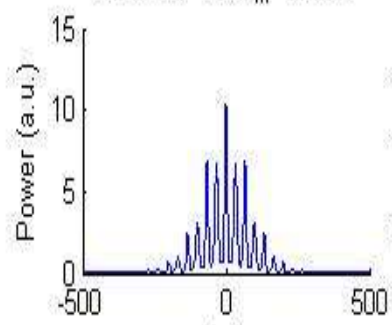

t(ps)

Roundtrip $=10, \mathrm{~F}_{\mathrm{m}}=20 \mathrm{MHz}$

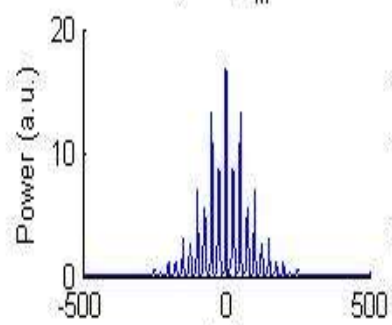

$t$ (ps)

Roundtrip $=10, F_{m}=25 \mathrm{MHz}$

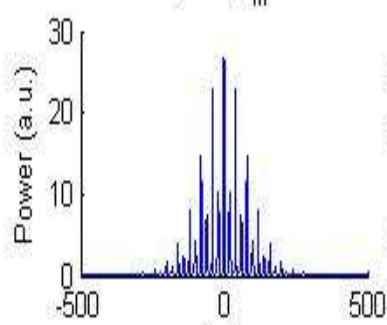

t(ps)

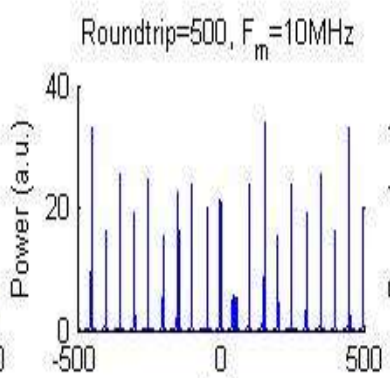

$t(p s)$

Roundtrip $=500, F_{m}=15 \mathrm{MHz}$

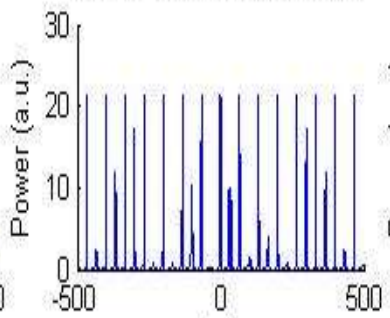

t(ps)

Roundtrip $=500, \mathrm{~F}_{\mathrm{m}}=20 \mathrm{MHz}$

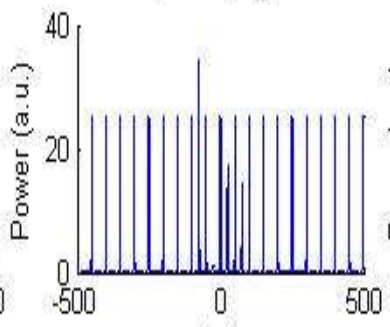

$t(p s)$

Roundtrip=500, $\mathrm{F}_{\mathrm{m}}=25 \mathrm{MHz}$

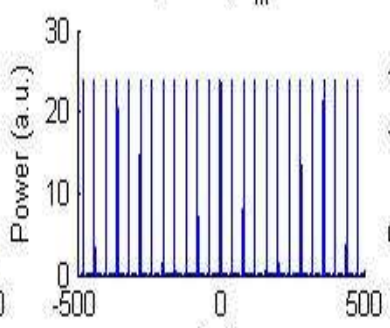

típs)

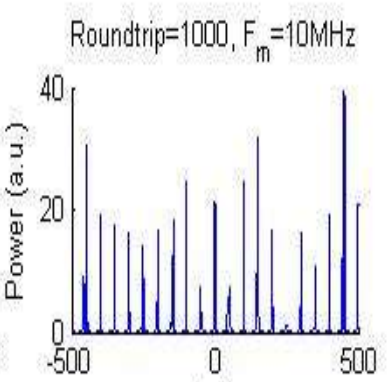

t(ps)

Roundtrip $=1000, F_{m}=15 \mathrm{MHz}$

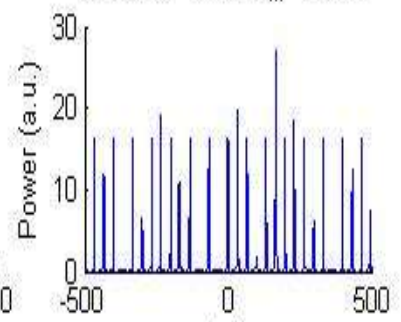

t(ps)

Roundtrip $=1000, F_{m}=20 \mathrm{MHz}$

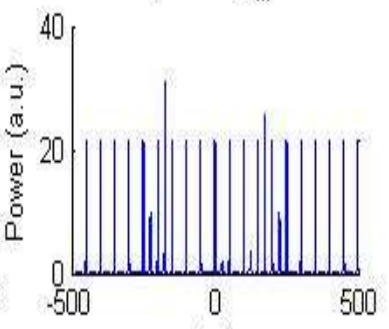

$t(p s)$

Roundtrip=1000, $F_{m}=25 \mathrm{MHz}$

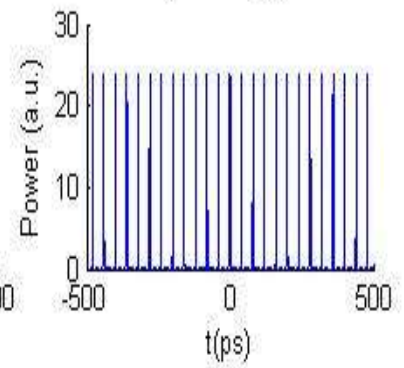


University of Thi-Qar Journal Vol.12 No.1 Mar 2017

Web Site: https://jutq.utq.edu.iq/index.php/main

Email: journal@jutq.utq.edu.iq

Fig.(3):The segmented process into ultrashort roundtrip pulses for different values of $F_{m}$ and roundtrip using $R=50 \%$.
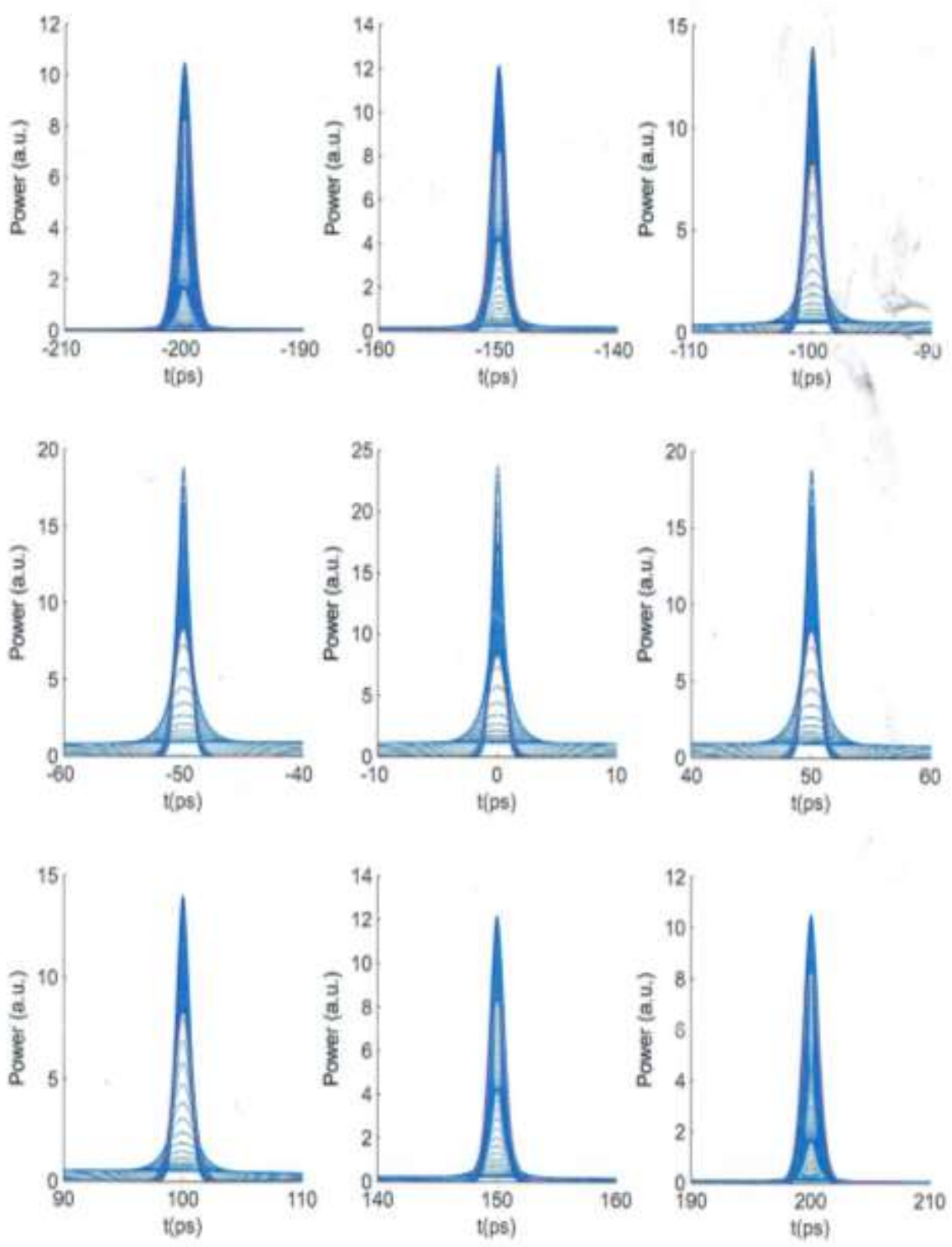

Fig.(4): The ultrashort roundtrip pulses that generate at the 
University of Thi-Qar Journal Vol.12 No.1 Mar 2017

Web Site: https://jutq.utq.edu.iq/index.php/main

Email: journal@jutq.utq.edu.iq

positions $0, \pm 50, \pm 100, \pm 150, \pm 200 p s$ for many roundtrip

,where the red line represents the final result. 


\section{University of Thi-Qar Journal Vol.12 No.1 Mar 2017 \\ Web Site: https://jutq.utq.edu.iq/index.php/main \\ Email: journal@jutq.utq.edu.iq}

\section{Conclusion}

In conclusion, the stream of ultrashort pulses is affected by $R, \mathrm{RT}$ and $F_{m}$, when the largest $F_{m}$ will require the smallest RT. The pump power will affect the gain $g_{0}$, so the resulted stream is much affected by the pump power. The presence of $\beta_{2}$ may be altered by the behavior of resulted power and energy. The other parameters $\beta_{3}, T_{0}, T_{2}$ and $\Delta_{F M}$ do not explain an important features on the resulted ultrashort pulses in terms of pulse duration and pulse energy.

\section{$\underline{\text { References }}$}

[1] G. Eduardo and V. Ib, "Continuous wave and pulsed erbium-doped fiber lasers for microwave photonics applications," no. November, 2012.

[2] F. Träger,. "Springer handbook of lasers and optics". Springer Science and Business Media, 2007.

[3] R. Quimby, " Photonics and Lasers An Introduction", John Wiley and Sone, Inc., 2006.

[4] G. P. Agrawal and H. a. Haus, Applications of Nonlinear Fiber Optics, vol. 55, no. 6. 2002.

[5] M. Premaratne, and G. Agrawal, "Light Propagation in Gain Media Optical Amplifiers", Cambridge University Press, 2011.

[6] P. W. Milonni and J. H. Eberly,."Laser Physics". by John Wiley and Sons, Inc. All rights reserved, 2010.

[7] Binh, Le, and Nam Ngo. "Ultra-Fast Fiber Lasers: Principles and Applications with Matlab Models." 2011.

[8] Weiner, Andrew. "Ultrafast optics". Vol. 72 John Wiley and Sons, 2011.

[9] A. Sennaroglu, ." Solid-state lasers and applications". Vol. 119. CRC press, 2006. 


\section{University of Thi-Qar Journal Vol.12 No.1 Mar 2017 \\ Web Site: https://jutq.utq.edu.iq/index.php/main \\ Email: journal@jutq.utq.edu.iq}

[10] N . Usechak,. "Mode Locking of Fiber Lasers at High Repetition Rates". Diss. University of Rochester, 2006.

[11] J. K. Shaw. "Mathematical principles of optical fiber communications". Vol. 76. SIAM, 2004.

[12] G. P. Agrawal, "Optical pulse propagation in doped fiber amplifiers." Physical Review A 44.11: 7493. 1991.

[13] E. J. Verdurmen,. "Optical time domain add-drop multiplexing employing fiber nonlinearities." Dissertation Abstracts International 68.022006.

[14] M. Watak, "Computational Photonics an Introduction with Matlab",

Cambridge University Press, 2013.

[15] J. Yao, and W. Yuyue. "Nonlinear Optics and Solid-State Lasers: Advanced Concepts, Tuning-Fundamentals and Applications". Vol. 164. Springer Science and Business Media, 2012.

[16] B. Mahdi "Numerical Analysis of Additive Pulse Mode Locking Fiber Laser", thesis M.Sc., University of Technology Laser and Optoelectronics Engineering Department,2009.

[17] A. M. Eldamak,. "High Power Linearly Polarized Fiber Lasers in a Linear Cavity." ,Ryerson University, 2013.

\footnotetext{
الخلاصة

في هذا البحث , تم ادخال جميع التأثيرات مثل : التتـت , اللاخطية , عامل الربح

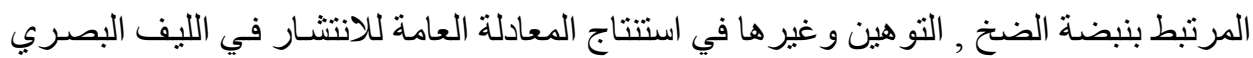

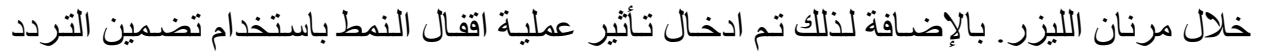
بغية الحصول على سيل نبضات فائقة القصر.

باختيار مناسب لتردد التضمين فأن سيل النبضـات المتحقق يمكن ان يصل الى مرحلة الاستقرار وفق عدد معين من رحلات الذهاب ـ العودة (RT) , حيث ان التردد الاعلى ير افقه

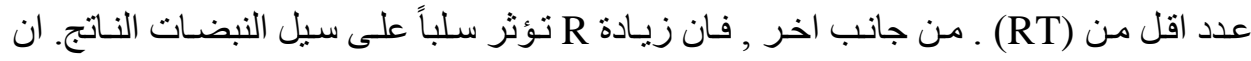




\section{University of Thi-Qar Journal Vol.12 No.1 Mar 2017}

Web Site: https://jutq.utq.edu.iq/index.php/main

Email: journal@jutq.utq.edu.iq

الفاصلة الزمنية بين النبضات الناتجة تتناسب عكسيا مع تردد التضمين. سيل النبضـات يمكن ان

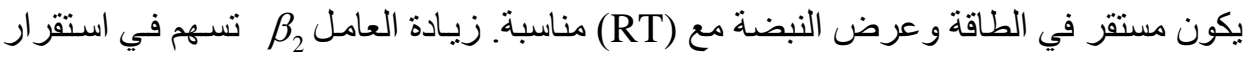

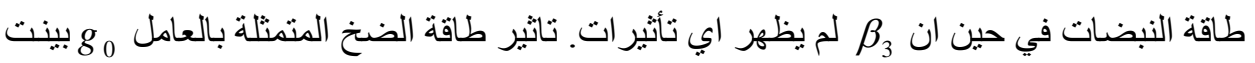

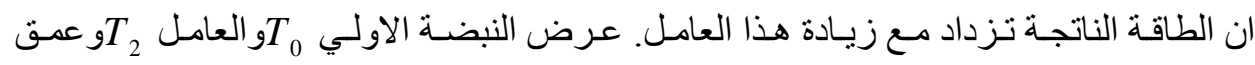
التضمين تتمثل تأثثير اتها بتغير اسلوب التذبذب لعوامل النبضات الناتجة. 